\title{
RECENT ASPECTS ON GLUCOSE-6-PHOSPHATE DEHYDROGENASE
}

by

\author{
GIAN FRANCO GAETANI and EMANUELE SALVIDIO
}

Cattedra di Ematologia, Universita di Genova

Viale Benedetto XV. N.6. Genova, Italy

Keywords: Human G6PD

\section{INTRODUCTION}

Glucose-6-phosphate dehydrogenase (G6PD) deficiency is the most common disease producing enzyme deficiency of human beings. Knowledge about G6PD deficiency was preceeded by observation on screeningly unrelated hemolytic response to various drugs and toxic substances, and several authors observed that just before the red cell underwent destruction the level of reduced glutathione (GSH) fell. Hemolytic anemia following the administration of pamaquine was first reported in 1926 (6) and as early as 1928 Heinz bodies were noted in the red cells of a patient with pamaquine induced hemolysis (28). In 1956 CARSON et al. (3) demonstrated that the activity of G6PD was greatly reduced in erythrocytes of some American subjects of African origin sensitive to primaquine, an antimalarial drug which also caused, both in vivo and in vitro, a depletion of GSH (32). In the same time SANSONE et al. (31) noted that the susceptibility to drug induced hemolytic anemia and to favism occurred in the same persons and they also demonstrated that such people had low level of GSH (31).

G6PD is the first enzyme of the hexose monophosphate shunt (HMS) and together with 6 phosphogluconate dehydrogenase (6PGD) is the principal NADPH generating system of human red cell. Since the product of G6PD becomes the substrate for 6PGD, G6PD deficiency represents a double handicap in the ability to generate NADPH. NADPH is necessary for the regeneration of glutathione from the oxidized form (GSSG) via glutathione reductase (GSSG R).

The mechanism by which this deficiency of GSH leads to destruction of the red cell is not yet completely clarified. COHEN and HoCHSTEIN (4) emphasize the role of GSH as a substrate for glutathione peroxidase and the failure of G6PD deficient cells to detoxify the intracellular peroxides that result from the action of primaquine and related drugs. This in turn will cause a peroxidation of several components of the red cells (hemoglobin, enzymes, membrane) causing to the cell irreversible damages. 


\section{GENETIC HETEROGENEITY OF G6PD}

Within a few years from the discovery of G6PD deficiency it was evident that a great genetic variability of this enzyme existed. But until standardization of methodology was achieved, it was impossible to determine whether an enzyme purified in one laboratory was the same as that which had been examined elsewhere. In 1967 international agreement was reached regarding methods of standardization (2) and until now about 250 variants have been described.

One might suggest three possible explanations for this great genetic variability:

1) Mutational: That is the G6PD gene is really more mutable.

2) Selection: A genetic polymorphism can in general arise through operation of drift or of selection. G6PD mutants may be more likely than mutants in other genes to have a positive selective advantage and the only likely candidate to have done this job is Plasmodium Falciparum $(22,23)$.

3) Bias in detection: Among human proteins, G6PD is one of those which have received the most attention, because the gene for G6PD is X linked and the production of a single gene can be isolated in the pure form from the tissues of male. The full expression of the enzyme will be seen among q males, while a corresponding autosomal defect would be seen only among $\mathrm{q}^{2}$ subjects.

It is likely, therefore, that the heterogeneity and prevalence of variants at G6PD locus more nearly reflect the real situation at other loci than they reflect unusual instability of the G6PD locus.

\section{BIOCHEMICAL ASPECTS OF G6PD}

Human G6PD is an aggregate of subunits and present evidence indicates that these subunits are identical $(16,36)$.

The enzyme polymer contains $\mathrm{NADP}^{+}$, and when this is removed, G6PD dissociates into monomeric subunits (20).

Activity of the $\mathrm{NADP}^{+}$stripped enzyme at various enzyme concentrations suggested a bimolecular reaction and a dimeric state of the enzyme.
The role of diffusion and sedimentation of the dissociated enzyme allowed an estimate of the molecular weight of the subunit of $52,000(5,20$, 36 ), while the rate of movement of the partially purified enzyme during ultracentrifugation in sucrose gradients, diffusion, gel filtration indicate that the molecular weight is 100,000 $110,000(20,30,35,36)$.

The amino acid composition of the enzyme has been determined, and a partial peptide map has been developed $(7,18)$.

\section{INTRACELLULAR REGULATION OF G6PD AND DRUG INDUCED HEMOLYSIS}

In normal red cells the intracellular concentrations of both substrates of G6PD, glucose-6phosphate (G6P) and NADP ${ }^{+}$are well below the saturating levels under normal conditions. In the normal red cell essentially all NADP is in the reduced form (21). Oxidative agents will decrease NADPH with concomitant increase of NADP ${ }^{+}$.

Since increased NADP $^{+}$will bring G6PD activity near saturation and decreased NADPH will remove an inhibitory effect, it is clear that the NADP ${ }^{+} / \mathrm{NADPH}$ ratio is the major modulator of G6PD activity.

G6PD deficient erythrocytes in unstressed conditions utilize $\left(1^{14} \mathrm{C}\right)$ glucose through HMS at a rate similar to the normal red cells but they are operating close to the maximal intracellular velocity (11). In the presence of methylene blue, a many-fold stimulation of HMS occurs in normal intact red cell, while the stimulation is milder in G6PD A ${ }^{-}$or minimal in G6PD Mediterranean variant. Activities of G6PD in hemolysates from normal and G6PD A erythrocytes is about 60 -fold the activity of the HMS in intact red cells of the same persons.

The large discrepancy between the activity of HMS in intact red cells and the corresponding hemolysates has been defined as "intracellular restraint" (11). This restraint is now on the way to be clarified, being related to two proteins binding NADP ${ }^{+}$and NADPH (15).

G6PD deficient red cells, in steady state conditions, have a low NADPH/NADP ${ }^{+}$ratio, thus allowing HMS to operate at its maximal intracel- 
lular rate and to compensate the intrinsic erythrocyte enzyme deficiency. A small increase in the oxidative rate induced by oxidizing agents caused a significant reduction in the NADPH/ NADP $^{+}$ratio (26). The extent of stimulation of HMS required to cause irreversible damage to G6PD deficient cells is not high. By the ${ }^{14} \mathrm{CO}_{2}$ evolution technique it was found that when normal erythrocytes are incubated in autologous serum, containing the active metabolites of ingested primaquine, the stimulation of HMS was only $15-25 \%$. Under these conditions there would be massive hemolysis in vivo in G6PDdeficient red cells.

\section{SCREENING TEST FOR}

\section{POTENTIALLY HEMOLYTIC DRUGS}

Most of the information regarding antimalarial drugs came from clinical studies or from deliberate in vivo administration to G6PD deficient volunteers or by the method of cross transfusion of G6PD deficient red cell to normal recipient subjects to whom the drug was given (13). Moreover, not all occasional reports can be considered valid, since several added factors such as infection, fever and acidosis may also be present and these disease states, rather than the drug itself, may be responsible for hemolysis. Because of these difficulties the need was greatly felt for an in vitro test that will reveal whether any particular substance, including a new drug, is potentially hemolytic for a G6PD deficient person.

A method derived from studies of regulation of HMS, has been recently introduced (12). It is based on incubating normal red cells in autologous serum after taking the drug, and thus presumably containing the active metabolites of the drug itself. If HMS stimulation by the technique of ${ }^{14} \mathrm{CO}_{2}$ evolution from $1{ }^{14} \mathrm{C}$ glucose is observed, the drug should be regarded as potentially hemolytic for G6PD deficient subjects. Two sulphonamides, for which no evidence of hemolytic effect had previously been reported prooved to be active by this test, and this correlated with data from the previously mentioned crossed-transfusion approach. Other drugs, on the other hand, have been tested by this method, and were proven to be potentially unhemolytic. They were safely administered to G6PD-deficient subjects without any hemolytic effect (25).

\section{MAPPING OF HUMAN G6PD GENE}

Although it is well known that the locus for G6PD is on the distal region of the long arm of the human $\mathrm{X}$ chromosome, its localization and order with respect to the centromer has been only recently established utilizing an $\mathrm{X}$ autosomal translocation. A unique and complex karyotypic rearrangement involving chromosomes $\mathrm{X}, 3,7$ and 21 has been reported. The break point on the $\mathrm{X}$ chromosome at the junction of Xq27 - Xq28 separates the loci for HPRT and G6PD.

Hybridization studies of proband's fibroblasts with mouse cells indicate that the human $X$ retained in hybrids expresses human HPRT and PGK, but segregates independently of human G6PD. Furthermore, the segment containing G6PD has been translocated to chromosome 21 . On the basis of these studies G6PD locus can be assigned to band $\mathrm{Xq} 28$.

Since blood cells and fibroblasts from the proband (a black female) do not express the maternal allele for G6PD, these studies provide biochemical evidence for non-random expression of X-linked genes in balanced X-autosomal translocation (27).

The availability of spontaneous and induced variants at these loci in humans has contributed to their usefulness for studying the basis of genetic phenomena, specifically the regulation of $\mathrm{X}$ chromosome activity. It is likely that these genes will provide the means to obtain and identify $\mathrm{X}$ chromosome specific DNA.

It has been possible to isolate the first $X$ specific DNA unique sequence from a partial library constructed from BAM $\mathrm{H} 2$ digested human DNA from cells with $\mathrm{X}$ chromosome polyploidy (34).

\section{CLONING OF G6PD GENE}

Recently G6PD cDNA sequences have been cloned. Human diploid fibroblasts were used to prepare an enriched G6PD specific mRNA. The preparation of $\mathrm{cDNA}$ from enriched $\mathrm{mRNA}$ was 
followed by annealing it to plasmid p BR 322 and transformation E. Coli MB101. Two out of 3470 colonies screened were positive for G6PD specific DNA. These clones were identified as containing G6PD sequences by a translation assay and Southern blot analysis of them yields a single band when hybridized to human DNA digested with endonuclease ECO RI. The band increases progressively with $\mathrm{X}$ chromosome dosage (29).

The knowledge of the G6PD gene would be very important because it may be representative of a large number of genes and could help to elucidate in detail the basis for various form of G6PD deficiency.

\section{G6PD AS AN INVESTIGATIVE TOOL}

The X-linked isoenzyme system of glucose-6phosphate dehydrogenase (G6PD) has been used to demonstrate, in affected heterozygous woman, the clonal origin of several myeloproliferative disorders, including chronic myeloid leukemia (10), primary polycythemia (1) and myelofibrosis (19). According to the LYON hypothesis (24) in each female cell only one $\mathrm{X}$ chromosome is genetically active. Thus, normal and neoplastic tissues of heterozygotes for G6PD will express enzyme mosaicism if derived from many cells, whereas a clonal origin will be indicated by the expression of one type of enzyme only. This approach has been confined to women heterozygous for $\mathrm{A}^{-}$and $\mathrm{A}^{-}$variants of G6PD, which are easily distinguishable from the normal B enzyme by electrophoresis. We have recently shown that the different utilization of 2-deoxy glucose-6-phosphate (2dG6P), an ana$\log$ of the normal substrate glucose-6-phosphate (G6P), by the normal enzyme and the Mediterranean variant of G6PD allows a convenient and accurate determination of mosaicism in cell populations from heterozygous individuals (8).

Since the normal enzyme utilizes 2dG6P less than $4 \%$ as rapidly as the normal substrate and the Mediterranean variant around $30 \%$, the utilization by the heterozygote is related to the degree of mosaicism. By this method we can detect a population of normal or G6PD deficient cells as small as $5 \%$. Clonal origin of primary thrombocytemia and erythroleukemia has been demonstrated by this technique $(9,14)$. The 2dG6P method may be of great value for prenatal diagnosis of $\mathrm{X}$-linked disorders, like hemophilia A of which close linkage with the G6PD locus is well recognized.

It is then possible to extend studies on the clonal origin of many neoplastic diseases and $\mathrm{X}$-linked immunodeficiency syndromes to women heterozygous for Mediterranean variant of G6PD.

\section{REFERENCES}

1. Adamson, J.W., P.J. Fialkow, A. Murphy, J.F. PrChal \& L. SteinmanN: Polycythaemia vera: stem cell and probable clonal origin of the desease. N. Engl. J. Med. 295, 913-916 (1976)

2. Betke, K., E. Beutler, G.J. Brewer, H.N. KirkMAN, L. Luzzatto, A.G. Motulski, B. Ramot \& M. SINISCALCO: Standardization of procedures for the study of glucose-6-phosphate dehydrogenase. Report of a WHO scientific group. WHO Tech. Rep. Ser. no. 366 (1967)

3. Carson, P.E., L.C. Flanagan, C.E. ICkes \& A.S. ALvING: Enzymatic deficiency in primaquinesensitive erythrocytes. Science 124, 484-485 (1956)

4. Cohen, P. \& Hochstein: Glucose-6-phosphate dehydrogenase and detoxification of hydrogen peroxide in human erythrocytes. Science 134, 1756-1757 (1961)

5. Cohen, P. \& M.A. Rosemeyer: Subunit interactions of glucose-6-phosphate dehydrogenase from human erythrocytes. Eur. J. Biochem. 8, 8-15 (1969)

6. CORDES, W.: Experiences with plasmochin in malaria. United Fruit Co. (Med. Dept.) 15th Annual Report, Boston, 66-71 (1926)

7. Deflora, A., A. Morelli, M. Frascio, G. Corte, B. Curti, M. Galliano, C. Gozzrer, L. MinChiotti, C. Mareni \& G.F. Gaetani: Radioimmunoassay and chemical properties of glucose 6 phosphate dehydrogenase and of a specific NADP(H)-binding protein (FX) from human erythrocytes. Biochim. Biophys. Acta 500, 109123 (1977)

8. Ferraris, A.M., P. Giuntini, S. Galiano \& G.F. GAETANI: 2 deoxy glucose 6 phosphate utilization in the study of glucose 6 phosphate dehydrogenase mosaicism. Am. J. Hum. Genet. 33, 307-313 (1981)

9. Ferraris, A.M., L. Canepa, C. Mareni, T. Meloni, E. Salvidio, G. Forteleoni \& G.F. GaeTANI: Reexpression of normal stem cells in eryth- 
roleukemia during remission. Blood 62, 177-179 (1983)

10. Fialkow, P.J., S.M. Gartler \& A. Yoshida: Clonal origin of chronic myelocytic leukemia in man. Proc. Natl. Acad. Sci. 58, 1468-1472 (1967)

11. Gaetani, G.F., J.C. Parker \& N.H. Kirkman: Intracellular restraint: a new basis for the limitation in response to oxidative stress in human erythrocytes containing low activity variants of glucose-6-phosphate dehydrogenase. Proc. Natl. Acad. Sci. USA 71, 9, 3584-3587 (1974)

12. Gaetani, G.F., C. Mareni, R. Ravazzolo \& E. SALVIDIO: Hemolytic effect of two sulphonamides evaluated by a new method. Br. J. Haematol. 32 , 183-189 (1976)

13. GaETani, G.F. \& L. Luzzatto: Hemolytic reactions induced by drugs and other agents: the role of red cell enzyme abnormalities and of abnormal hemoglobins. In: Pseudo Allergic Reactions. Involvement of Drugs and Chemicals, P. Dukor, P. Kallos, H.D. Schulumberger and G.B. West, eds., Basel, S. Karger, Vol. 2, pp. 1-19 (1980)

14. Gaetani, G.F., A.M. Ferraris, S. Galiano, P. Giuntini, L. CANePa \& M. D.URso: Primary thrombocythemia: clonal origin of platelets, erythrocytes and granulocytes in a GdB/Gd Mediterranean subjects. Blood 59, 76-79 (1982)

15. Gaetani, G.F. \& H.N. Kirkman: Regulation of normal and mutants glucose-6-phosphate dehydrogenase by NADP-binding proteins. Amer. Soc. Human Genetics 34th Meeting, Norfolk, Va., (1983)

16. GaRTLER, S.M., R.M. Liskay, B.K. CAMPBELL, R. SPARKES \& N.GANT: Evidence of two functional $X$ chromosomes in human oocytes. Cell Differentiation 1, 215-218 (1972)

17. HARRIS, $H$. : The principles of human biochemical genetics, Amsterdam, North Holland, 2nd Edition (1975)

18. Huang, I.Y. \& A. Yoshida: Unpublished (1976)

19. JaCobson, R.J., A. SALO \& P.J. FialKow: Agnogeic myeloid metaplasia. A clonal proliferation of hematopoietic stem cells with secondary myelofibrosis. Blood 51, 189-194 (1978)

20. KiRKMAN, H.N. \& E.M. HendRICKON: Glucose-6phosphate dehydrogenase. II. Subactive states of the enzyme from normal persons. J. Biol. Chem. 237, 2371-2376 (1962)

21. Kirkman, N.H., G.F. Gaetani, E.H. Clemons \& C. MARENI: Red cell NADP ${ }^{+}$and NADPH in glucose 6 phosphate dehydrogenase deficiency. J. Clin. Invest. 55, 875-878 (1975)

22. Luzzatto, L.: Genetics of red cells and susceptibility to malaria. Blood 54, 5, 961-976 (1979)

23. Luzzatto, L., E.A.USANGA \& S. RedDY: Glucose- 6-phosphate dehydrogenase deficient red cells: Resistance to infection by malarial parasites. Science 164, 839-842 (1969)

24. LYON, M.F.: Chromosomal and subchromosomal inactivation. Ann. Rev. Genet. 2, 31 (1968)

25. Meloni, T., G. Forteleoni, M. Serra, S. Daniotti, L. Negri, P. Giuntini, L. Canepa, G.F. GAETANI: Feprazone absence of hemolytic effects in glucose-6-phosphate dehydrogenase deficient subjects. J. Clin. Pharmacol. 22, 418-420 (1982)

26. MARENI,C \& G.F.GAETANI: NADP ${ }^{+}$and NADPH in glucose 6 phosphate dehydrogenase deficient erythrocytes under oxidative stimulation. Biochim. Biophys. Acta 430, 395-398 (1976)

27. Pai, G.S., J.A. SpRenkle, T.T. Do, C. Mareni \& B.R. Migeon: Localization of loci for hypoxanthine phosphoribosyltransferase and glucose 6 phosphate dehydrogenase and biochemical evidence of non random $X$ chromosome expression from studies of a human $X$ autosome translocation. Proc. Natl. Acad. Sci. USA 77, 2810-2813 (1980)

28. Palma, M.D.: Plasmochin therapy in malaria. Riforma MD. 44, 753-756 (1928)

29. Persico, M.G., D. Toniolo, C. Nobile, M. D.URSO \& L. LUzZATTO: cDNA sequences of human glucose 6 phosphate dehydrogenase cloned in p BR 322. Nature 294, 778-780 (1981)

30. RATTAZZI, M.C.: Glucose-6-phosphate dehydrogenase from human erythrocytes: molecular weight determination by gel filtration. Biochem. Biophys. Res. Commun. 31, 16-24 (1968)

31. Sansone, G. \& G. Segni: Prime determinazioni del glutatione ematico (GSH) nel favismo. Boll. Soc. Ital. Biol. Sper. 32, 456-458 (1956)

32. Sansone, G., G. Segni \& C. De Cecco: Il difetto biochimico eritrocitario predisponente all'emolisi favico. Prime ricerche sulla popolazione ligure e su quella sarda. Boll. Soc. Ital. Biol. Sper. 34, 1558-1561 (1958)

33. Testa, U., T. Meloni, A. Lania, G. Battistuzzi, S. CUTILlA \& L. LUZZATTO: Genetic heterogeneity of glucose-6-phosphate dehydrogenase deficiency in Sardinia.

34. WOLF, S.F., C.E. MARENI \& B.R. MigeON: Isolation and characterization of cloned DNA sequences that hybridize to the human $\mathrm{X}$ chromosome. Cell 21, 95-102 (1980)

35. YoshiDA, A.: Glucose 6 phosphate dehydrogenase of human erythrocytes. I. Purification and characterization of normal (B) enzyme. J. Biol. Chem. 241, 4966-4967 (1966)

36. YoshIDA, A.: Subunits structure of human glucose-6-phosphate dehydrogenase and its genetic implications. Biochem. Genet. 2, 237-243 (1968) 